\title{
Crystal structure of dolomites recrystallized at low vs. high water to rock ratios
}

\author{
GeORGINA LUKOCZKI ${ }^{1,2^{*}}$, PANKAJ SARIN ${ }^{3}$, JAY M. \\ GREGG $^{2}$, CÉDRIC M. JOHN ${ }^{4}$ \\ ${ }^{1}$ University of Kentucky, Kentucky Geological Survey, \\ Lexington, KY, USA \\ ${ }^{2}$ Oklahoma State University, Boone Pickens School of \\ Geology, Stillwater, OK, USA \\ ${ }^{3}$ Oklahoma State University, School of Materials Science and \\ Engineering, Tulsa, OK, USA \\ ${ }^{4}$ Imperial College London, Department of Earth Science and \\ Engineering, London, UK \\ (*Correspondence: gina.lukoczki@uky.edu)
}

Detailed geochemical and crystallographic analyses of recrystallized Middle Triassic dolomites from SW Hungary suggest variations in their crystallographic characteristics depending on whether recrystallization occurred at low or high water to rock ratios. Dolomites recrystallized at high water to rock ratios are coarser crystalline, less ordered and have more contracted unit cells than those recrystallized at low water to rock ratios. Dolomites that were recrystallized at low water to rock ratios display a trend of increasing cation order with increasing crystal size, and increasing crystal sizes are accompanied by increasingly expanded unit cells. Furthermore, cation ordering increases with increasing temperatures, determined using clumped isotopes $(\Delta 47)$, in dolomites recrystallized with low water to rock ratios. A strong correlation between unit cell volume, stoichiometry and lattice strain suggests that the unit cell volume is controlled by the amount of excess $\mathrm{Ca}$ in the dolomite lattice. However, the lack of a clear trend between cation ordering and unit cell volume suggests that the lattice strain is related to factors other than cation disorder. In matrix dolomites structural defects can be introduced into the dolomite lattice due to the anion orientation of the mineral that is being replaced [1]. Such defects may be preserved to some degree in recrystallized dolomites and cause the observed strain. Large amounts of syntaxial overgrowth cement on dolomites recrystallized at high water to rock ratios may result in an apparent lower overall strain due to the lack of such structural defects in overgrowth cements.

[1] Gunderson, S. \& Wenk, H. (1981) American Mineralogist 66, 789-800. 